\title{
"The Time Machine" Social Innovation and Research-Creation Strategy for Risk Control in Informal Labor Communities
}

Gregorio Enrique Puello-Socarrás, ORCiD: https://orcid.org/0000-00017507-5937 - Industrial Design / Business Administration Proffessional Safety and Health at Work Management Specialist - Master's degree in Development Practice. Teacher and Researcher at the Corporación Universitaria Minuto de Dios - UNIMINUTO Bogotá, Colombia. Email: gpuellosoca@uniminuto.edu.co,gregorio.puello@uniminuto.edu

Strategies to control occupational risk factors face various challenges in terms of their application and effectiveness, even more so when it comes to providing risk-control solutions under informal working conditions. Purpose: explore opportunities presented by the use of social innovation strategies and methodologies derived from research-creation to establish educational control measures for occupational risk factors, for recovery and recycling workers in Bogotá (Colombia). Methods and procedures: There were two main phases for this research: one aimed to understand the different risk posed to informal labor communities based on workplace inspection and risk assessment norms NTC4114 and GTC45, the other one was aimed to develop a research-creation and social innovation-based strategy, to co-create innovative solutions to address risk factors with the informal workers New Results: Risk conditions were measured for the first time with this group of informal workers and a social innovation creation was made to control risk factors and to dignify working conditions Conclusions: Informal work has precarious and uncontrolled risk. In addition, the systematic exclusion of informal workers from public health labor systems organized by national governments means that protective measures for this group of people are often ineffective or inadequate, or in the worst case, non-existent.

Key words: Education of the population; public perception of science; projects of social investment 


\section{INTRODUCTION}

The identification and management of occupational risk factors among informal workers is a field of study that is scarcely investigated worldwide, despite the challenges they pose in terms of public health. Similarly, controls and strategies for prevention have fields of action limited by the dynamics they present in the context of informal occupations and the absence of practices and clear regulations in regard to the development of interventions with these communities.

The objective of this article is to present the results of a research project in the year 2019 involving a group of informal workers and actions taken together with these work communities, in order to co-create strategies for the prevention and management of risks associated with informal work activities. In a previous work, published by the author with other researchers and called "Report of risk factors in informal waste recovery workers in the town of San Cristóbal - Bogotá" (Puello-Socarrás, Obregón, Serna and Ballén, 2021) the results of the data collection on occupational risks and hazards in the workplace were presented in a preliminary way, when the project was in the process of development and had obtained partial results.

This present article addresses in greater detail and depth, not only the results obtained from the research instruments related to health and safety conditions in informal work, but also presents and explains the social innovation strategy, based on media audiovisuals used as a communicative trigger to inspire people in the creation of control measures for the risk factors and hazards to which workers are exposed, and also allowing the author to reflect on these methodologies and strategies to tune up his methods for future applications.

For this matter, based on the following methodologies:

(1) One defined by the Parque Científico de Innovación Social (PCIS) attached to the Corporación Universitaria Minuto de Dios (UNIMINUTO) in Bogotá, Colombia;

(2) The so-called methodology of social innovation of PCIS (Arias, 2016), which is inspired on the methodology of social innovation of the Innovation School (I-School) from the University of Tokyo,

(3) Research-creation as a strategy for obtaining data and information,

In order to inspire community knowledge appropriation, a workshop made by the author and called "The time Machine" is presented and used as a way to try and solve the issue of an informal workstation risks and hazards. 
The author intends to discuss the relevance of alternative methods of intervention for problems of safety and health at work, especially in scenarios such as that of Colombia, which by their size and impact are not only occupational health problems but public health issues because of the size and dimension of the conditions of informal labour in the majority of developing countries.

\section{Labour informality as a factor of social conflict and pressure on systems of national health}

According to the International Labour Organization (ILO):

Decent work summarizes the aspirations of people during their working life. It means the opportunity of accessing gainful employment that generates a just income, workplace security and social protection for families, better prospects for personal development and social integration, freedom for individuals to express their opinions, organization and participation in decisions affecting their lives, and equality of opportunity and treatment for all women and men. (OIT - ILO, 2020)

However, the definition of this concept does not in theory suppose any conflict that can be perceived from what has been proposed. The real conflict is in the day-to-day struggle to fulfill those aspirations for each of the millions of men and woman that strive and suffer every day to work and survive in precarious conditions at the global level, which according to ILO estimates represent more than the $60 \%$ of the total working population, i.e., about two billion people. “(...) Most lack social protection, worker rights, and decent working conditions." (OIT - ILO, 2018)

In the Colombian case, it is estimated that around 11 million people work in informal conditions and a good portion of these work in precarious conditions (LaboUR, 2018). This generates a factor of social conflict not effectively and appropriately recognized in Colombia and constitutes a challenge to national development of epic proportions, an undetermined burden on occupational health and safety systems, which ultimately affects not only the informal working population but the entire social fabric of nations.

\section{Structure of the conflict, characteristics and elements}

It can be said that the factor of social conflict varies between a "normalization" of its anomalous character, between consensualist and conflictivist theories (Lorenzo Cadarso, 1995). For this atypical conflict, elements of Marxist theory can be used to correspond to a social structure, modes of production and work, exposing it as another stage of the class struggle between proletarians and the bourgeoisie. It is a neuralgic point of the management of human and social conflict since work and access to it and the production of value represent the main engine of social change. On the other hand, the absence of structures for 
monitoring working conditions, risk factors associated with these activities, and illnesses and accidents during work generate pressure on health systems that affect the entire social fabric.

Taking into account theories of violence, it can be said that the aforementioned omission and lack of solidarity of the state and of the social group toward this marginal population group sustains a systematic oppression of the worker through exclusion from access to adequate means of production and, therefore, exclusion of access to and enjoyment of decent wages and conditions in which to perform work. This in turn generates processes of dependency and domination, products of inequality and precariousness, which are configured as a type of low-intensity violence that Sachs (2009) called "the poverty trap."

This "poverty trap" represent a ballast for informal workers to achieve better working environments and decent living conditions. This is because their workstations are not healthy and safe enough to sustain their working activities without risking their health and/or lives throughout the years, thus making them harder to get over the poverty line, preventing their productivity and ability to produce greater value out of their jobs, and in this way restricting their possibilities of taking advantage of that value for their economic growth or ensuring their future at the end of their lifespan.

As a result, not only informal workers are affected, but national health systems are also saturated and overburdened as they bear the full brunt of these precarious health conditions.

On the other hand, labour markets are also affected since the situation of workers formally hired by companies is undermined in their hiring conditions, as there is a labour surplus that can be used by industries; an incentive to generate spurious contracts for a workforce that can be easily replaced by those who may be in a position to accept increasingly precarious jobs, in the hope of overcoming the even poorer conditions of labour informality.

This is the root of a conflict, which according to a statement made by Lederach (1992), can be described in its characteristics in the way portrayed in figure 1: 


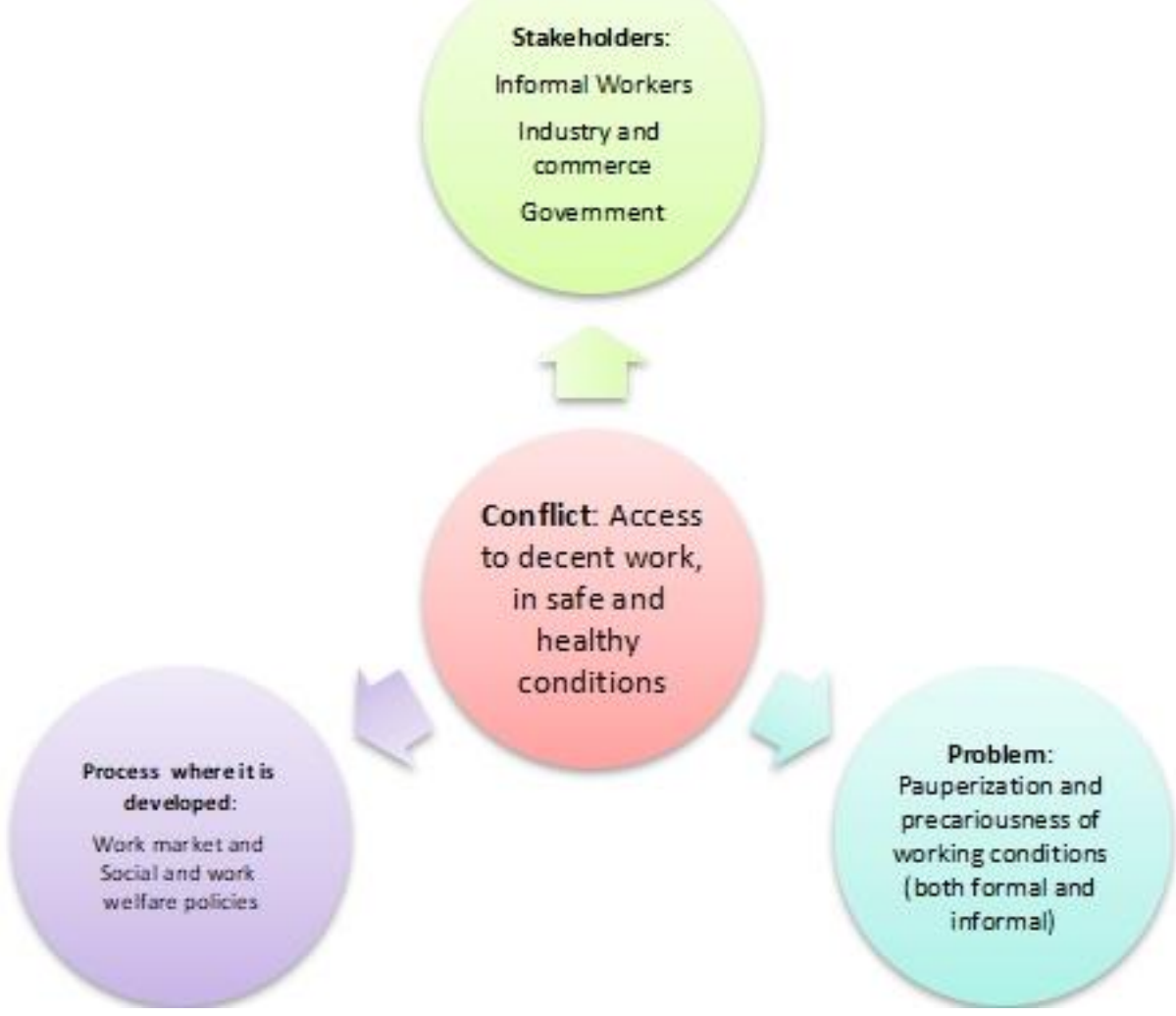

Figure 1. Triangle of Lederach with description of the conflict on decent work. Source: Own design based on (Lederach, 1992)

In this conflict, a structural typology is identified in accord with Fisas (1987), given that it comprises a large-scale problem, with opposing and incompatible interests of various social groups and the potential to generate large mobilizations, such as the recent demonstrations that are taking place in Colombia within the framework of the "paro nacional"(national strike), which cry out, among other things, for better working conditions and dignity in health care for all Colombians. (Pardo, 2021)

There are certain levels of understanding of the complex reality of the present conflict around decent work:

The first level is the level of commitment of the actors around the issue, which classifies them as primary, secondary and tertiary, depending on their level of interest and influence.

The second level corresponds to the possible conflictive processes between themselves and with others, classified as intrapersonal, interpersonal and intragroup conflicts.

The third level refers to the level of relationship with the other actors, which can be symmetrical or asymmetric. 
Finally, the fourth level corresponds to the nature of its objectives, which classifies them as concrete or symbolic due to their degree of explicitness.

This classification for all groups of actors involved in the conflict of decent, safe and healthy work can be seen in figure 2 , as follows:

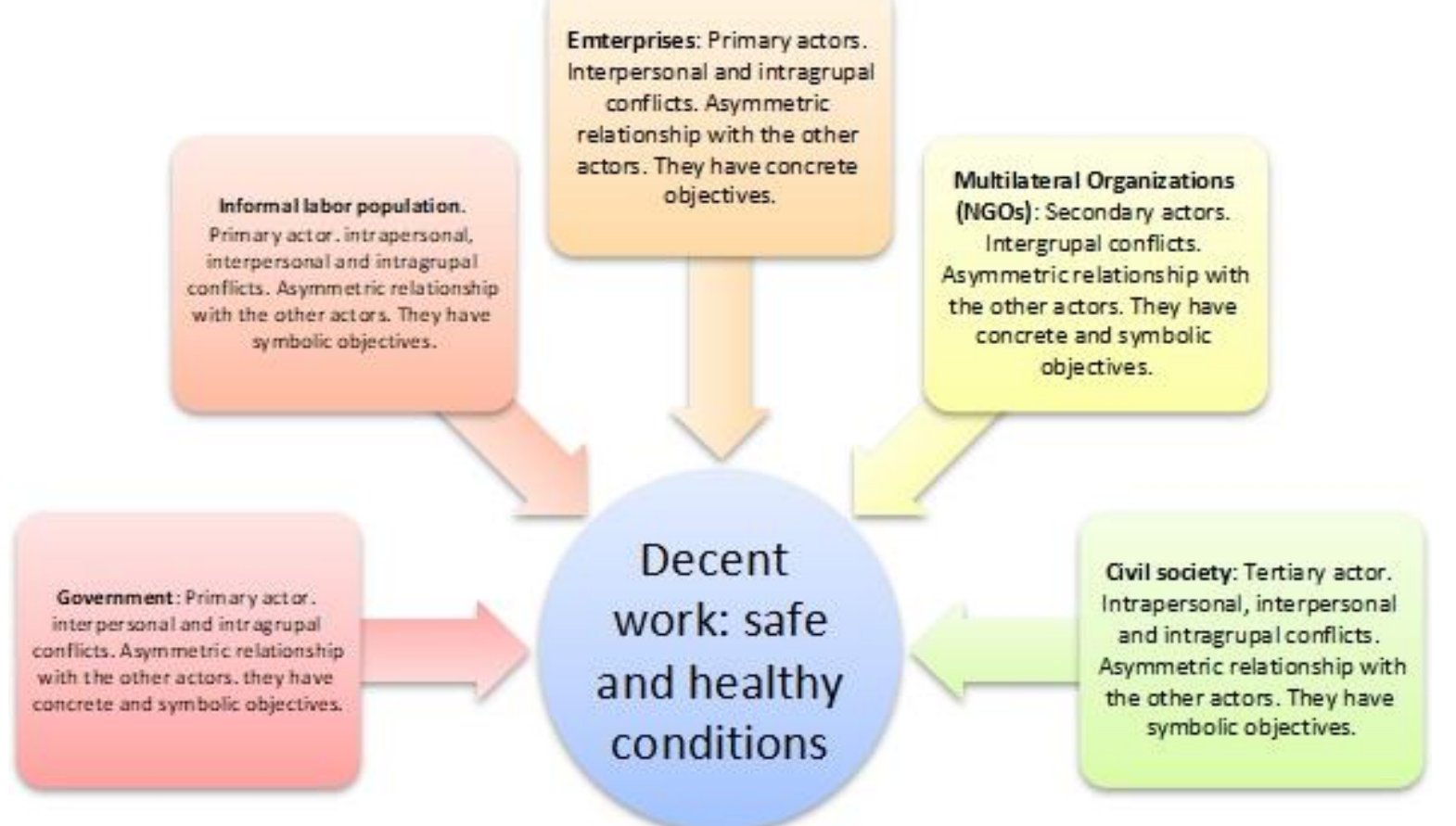

Figure 2. Actors of the conflict, their characteristics, relationships and objectives towards decent work issue. Source: Own design based on Fisas (1987)

Faced with this reality, it is important to establish that alternative solutions to the conflict, in spite of their manifest urgency, are scarce. This is because of the divergent interests of social groups and absence of effective public policies in protecting the interests of marginalized (informal) employees for the benefit of macroeconomic policies that have traditionally benefited capital and owners of the means of production, stimulating the reproduction of large-scale and systematic precarious labour, favouring informal labour.

\section{The urgent need for alternative control measures in informal work settings}

Presently, the protection and sustainable use of the environment is a priority issue on the global agenda. The changing climate and proper use of natural resources, particularly nonrenewable ones, are discussed in major political, economic, social, and scientific meetings around the world. In addition to the above, the social aspect cannot be neglected. In this matter, Puello-Socarrás stated:

(...) speaking of dignity in work, one refers specifically to the creation of a concept of employee welfare, which was established in a political-social-cultural context 
attempted in Colombia through established regulations of Safety and Health at Work, which in the words of Lizarazo, Fajardo, Berrio \& Quintana, are considered one of the "(...) more advanced in the world..." (2011) despite their manifest ineffectiveness, especially in regard to the prevention of diseases and accidents; however, they constitute the primary objective of the policies of Safety and Health at Work and the measure of its success." (Puello-Socarrás in Peña-Lapeira, 2019)

Having advanced legislation on safety and health at work has certainly not closed the gap. As will be seen later in this paper, the occupational risks and hazards to which informal workers are exposed are far from being controlled. At first instance, they have been scarcely studied and in many cases the difficulties involved not only in data collection, but rather the implementation of solutions or control measures, makes the legislation a dead letter.

When trying to establish control measures, there are three ways to eliminate these dangers and minimize risks: the first is engineering control (machine and workstation designs), the second is process and procedural control (administrative and equipment) and the third is knowledge control and self-care.

This last control measure is essential to complement and cement the other two, ensuring the well-being of employees in their work.

That is why the main interest of the social innovation strategy explores the human factor and the knowledge capital about the risks and hazards for their labour, as the keys that integrate the essential aspects of communication and social appropriation of knowledge as a means to successfully achieve these objectives.

For this purpose, it is important to take into account authors such as Berlo, who states that "(...) language is only one of the codes that we use to express our ideas", (1969) and that it is in the same line of thinking of authors such as Bateson \& Ruesch (1984) who identified multiple levels of communication, including the visual - and beyond - the audiovisual media, as a way to integrate different expressions and languages at multiple levels and for multiple audiences.

More recently, Jorge Frascara, for similar communication purposes between different actors, indicated:

For communication strategies to affect people's knowledge, attitudes or behaviour, they must be detectable, discriminatory, attractive, understandable and convincing. They should be built on the foundation of a good understanding of visual perception and the psychology of knowledge and behaviour, and should consider the personal preferences, intellectual abilities, and cultural value system of the target audience. (2000) 
Taking into account the previous communication concepts, both the World Health Organization (WHO) and the Pan American Health Organization (PAHO) have proposed specific communication and dissemination strategies as central elements in the prevention of health problems and mitigation of risk factors in work, formal and informal communities.

Figure 3 presents the Workplace Health Promotion Strategy (WHPS), with its main elements: assessment, planning and management, implementation and evaluation.

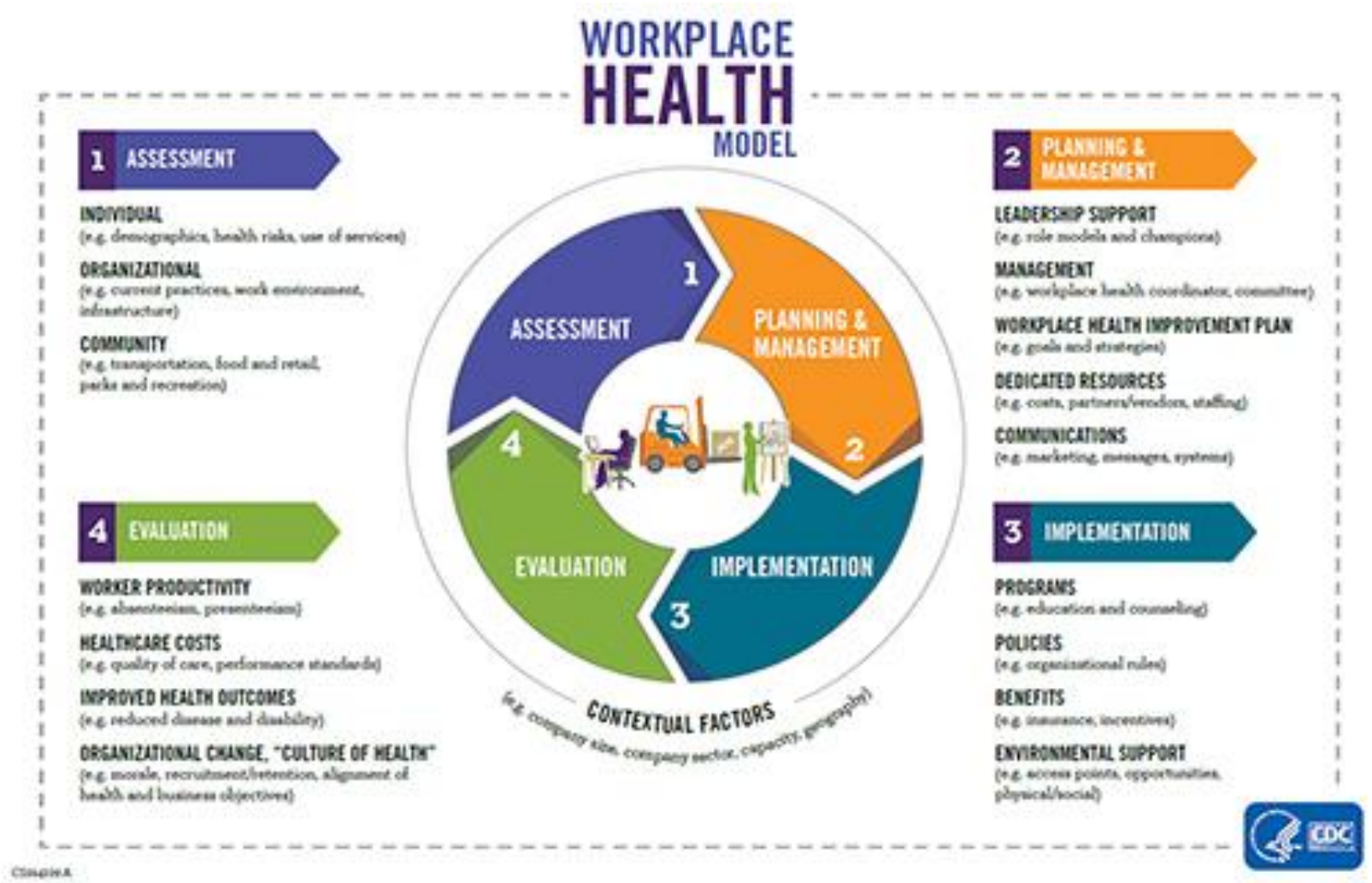

Figure 3. The Workplace Health Promotion Strategy (WHPS) model. Source: CDC (2016)

The main objectives of the strategy are the following:

- Develop a participatory and empowering character

- Promote multi-sectoral and multidisciplinary cooperation

- Encourage social justice

- Focus on sustainability

Subsequent to these guidelines described by WHO and PAHO, Chaves Bazzani reviewed the implementation of the WHP strategies in workplaces, through a "(...) review of literature of national and international agencies and of the Embase, ScienceDirect and Scielo databases between 2004 and 2014" (Chaves Bazzani, 2020); in this document, attention was focused on 
the fact identified by Chaves Bazzani that in the study, WHPS application was restricted to the business environment and promotion for informal jobs was minimal. On the other hand, the document identified that despite the spirit of WHPS from the Declaration of Luxembourg, the WHPS should be oriented toward "(...) improving the organization, working conditions, active participation, and individual development of workers, "the majority focused on "(...) reduction of risk factors, disease prevention, and intervention into individual habits."(Chaves Bazzani, 2020)

This remarkable lack of focus on informal workstations during the first ten years of the strategy implementation (2004-2014) evaluated in the Chaves Bazzani document leads to the conclusion that the exclusion in the approach and study of the working conditions of informal jobs and the perceived disinterest of national and international organizations in this field arose from a lack of preparation and participation of the academics and students in developing the solutions, due to lack of experience or lack of methodologies to address the issue. This way, faculties and programs in Safety and Health at Work should pay attention to the structural conditions of this problem. This issue of the informal labour vulnerability to labor risks and hazards has been systematic for more than 30 years $^{1}$, and involved half of Colombia's population, become a chronic and structural problem of public health in Colombia. (Puello-Socarrás \& Vargas Puentes, 2019)

Complementing the above, the ILO has recommended lines of action in regard to the ownership of community knowledge and processes of social change for the working population and companies. Their document "Strategies for Local Development" defines those strategies as "(...) integrated and participatory approaches anchored in social dialogue, which permit comprehensive and localized responses" in support of workers and employers. The union of local governments, social partners and organizations of civil society around workers and companies effectively facilitates the attainment of decent work and sustainable livelihoods by these groups. (ILO, 2018)

Moreover, the ILO in its document "Transition from the informal economy to the formal economy" reinforced the previous idea when it stated that the problem of labour and social marginalization "(...) is characterized by an acute deficit of decent work and a disproportionate percentage of working poor."(ILO, 2014) Within this field, "(...) workers in the informal economy regularly face greater risks of poverty (...)" and concludes by stating that "(...) there is a significant coincidence (...) between working in the informal economy and being poor and vulnerable"(ILO, 2014). Finally, the ILO has maintained a constant concern and has researched the problem, making important efforts in encouraging the scientific community to develop strategies that help to overcome the problem.

\footnotetext{
${ }^{1}$ Since the beginning of the statistical surveys carried out by DANE, a government agency responsible for economic data gathering and processing in Colombia
} 


\section{Social innovation and research-creation as a research tool of UNIMINUTO for risk management in environments of informal labour}

In contrast to the situation raised in the previous paragraph, a series of projects has been proposed in Corporación Universitaria Minuto de Dios - UNIMINUTO with the intention of contributing and implementing solutions based on social innovation and research-creation techniques, with the purpose of contributing to the generation of knowledge around the subject of decent, healthy and safe work with innovative and creative techniques. This projects were designed and applied in the following fields of study:

- Social Innovation for Communication of Labour Risk Factors for Informal Recyclers in the Locality of San Cristóbal Sur - Bogotá (2019)

- Social Innovation Strategy focused on the appropriation of knowledge about risk factors for health and occupational safety in informal workers of mining industries in PDET $^{2}$ territories, the south of Bogotá and Villavicencio (2020)

- Exploratory study of the working conditions and psychosocial risk factors in informal bike-delivery workers associated to digital apps in the main cities of Colombia (2021)

All of them were designed to apply social innovation and research-creation techniques in a trial and error scheme, with a view to refining and fine-tuning these methodologies to make a proposal for a social innovation route for decent work, which is finally promoted in the research result book "Safety and Health for the informal worker - Route of social innovation for decent work" (Puello-Socarrás y Ballén, 2021) which addresses concerns about processes for the management of risk factors for informal working populations, portraying different academic developments aimed to understand the risk factors for health and safety in informal workstations, and a proposal that includes new ways to address these problems in the field of occupational health, building a Route of social innovation for decent work based on these learning and creative research processes.

For the above purpose, the Research Directorate of UNIMINUTO, with support from the Occupational Safety and Health Administration programme, prepared the project under the precepts of the research line "Social Management, Participation, and Community Development" established within UNIMINUTO, which is defined as follows:

The management of possible futures, participation and community development is central within the institutional educational project of UNIMINUTO. Issues such as the co-production of knowledge with communities, the active participation of these in the search for and construction of solutions to problems confronted, the social

\footnotetext{
2 Territorial-Focused Development Plans -TFDP (PDET in spanish) A government compromise derived from the FARC Colombian government peace agreement of 2016, where some rural areas formerly contested in the armed conflict were prioritized to address some issues regarding productivity, informality and development for their communities.
} 
management of development, the empowerment of grassroots communities, and the educational community are relevant to this line. (UNIMINUTO, 2020)

To complement this framework of research action by UNIMINUTO, the Occupational Safety and Health Administration programme adopted within its structure of research development a sub-line called "Safety and health at work for high-impact and special interest populations Health and safety in informal work".

Within this line of research defined by the programme, social innovation strategies have been developed in response to the growing need for the transmission of knowledge on good management practices for safety and health in informal work settings.

For the purpose of this article, the 2019 project "Social Innovation for Communication of Labour Risk Factors for Informal Recyclers in the Locality of San Cristóbal Sur - Bogotá" will be examined in more depth to discuss its results and developments in order to integrate these reflections into the applicable methodologies in the other two projects, which are still in progress.

In the specific case of the aforementioned project, there is integration of the need for management of the proper disposal of domestic waste as a control measure against the occupational hazards identified in the informal activity of recycling among this population in the city of Bogotá.

The structure of this institutional initiative is portrayed in the following figure:

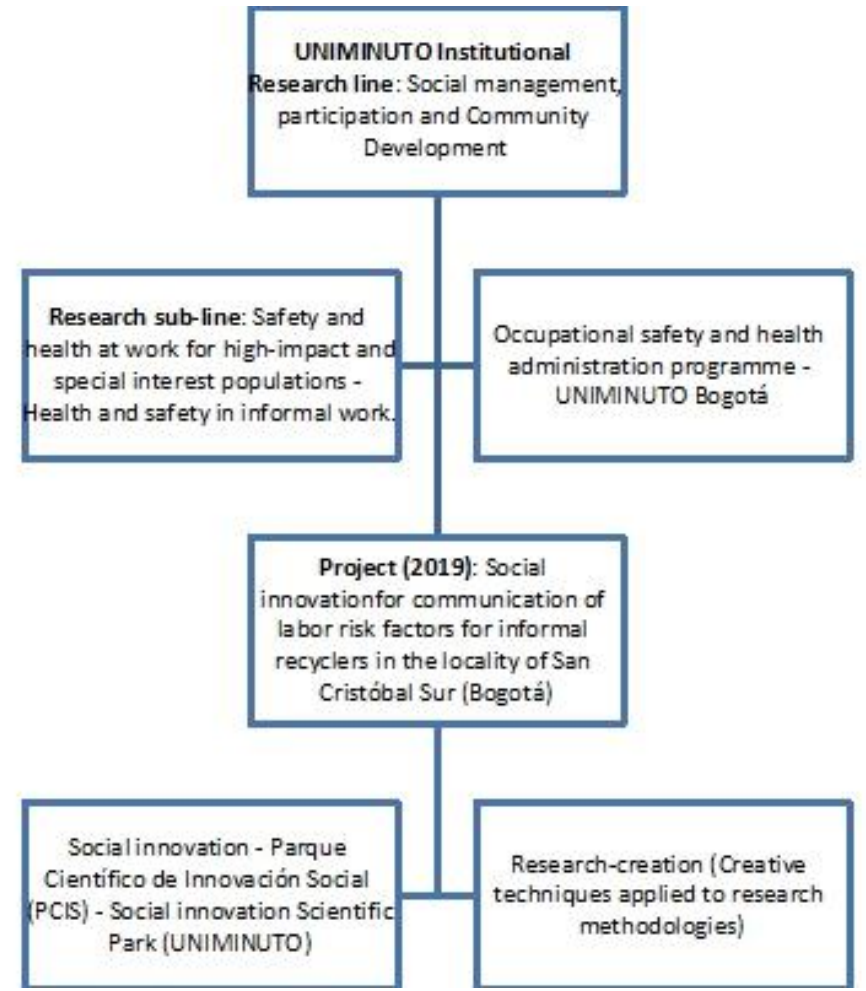


International Journal of Innovation, Creativity and Change. www.ijicc.net

Volume 15, Issue 10, 2021

Figure 4. Development structure of research projects in UNIMINUTO for the management of occupational risk factors in informal work. Source: Own design based on UNIMINUTO (2021)

\section{Social Innovation for Communication of Labour Risk Factors for Informal Recyclers in the Locality of San Cristóbal Sur - Bogotá - in depth review}

The general and specific objectives of the project "Social Innovation for Communication of Labour Risk Factors for Informal Recyclers in the Locality of San Cristóbal Sur - Bogotá" were established in the following manner:

\section{General objective:}

To develop a social innovation strategy focused on self-care and control measures of work risks to which informal recyclers are exposed in the town of San Cristóbal Sur in Bogotá.

\section{Specific objectives:}

1) To do cross-sectional fieldwork on social and occupational risk factors of informal recyclers in the town of San Cristóbal Sur, using participant observation and social mapping as research techniques.

2) To contextualize social and occupational risk scenarios for exposed informal recyclers in the town of San Cristóbal Sur in Bogotá, using the standard GTC45.

3) To disseminate project results in national or international contexts through the creation of research products endorsed by UNIMINUTO.

For the purposes of the present article, the author examine with greater emphasis the results of specific objective No. 1 and those of the general objective, which correspond to the social innovation strategy of community knowledge-appropriation and which was build through a research product defined by the Ministry of Science, Technology and Innovation of Colombia (formerly Colciencias) in the following manner:

This strategy seeks to promote a social appropriation of knowledge, understanding by this a process of understanding and intervention of the relations between technoscience and society, built from the active participation of the various social groups that generate knowledge. This process has the following characteristics: 1. It is intentional. 2. In the socio-technical network that constitutes it, social groups that are expert in science and technology intervene; the various sectors that take part in the constitution of these processes generate mediations. 3. It is a process in which civil society is empowered through knowledge. 4. Appropriation is not alienation; it implies even in the most asymmetric relationships translation and assembly within the frames of reference of the participating groups. (Colciencias, 2020) 
Later, the relationship with innovation is mentioned in the following way:

The social appropriation of knowledge is the foundation of any form of innovation because knowledge is a complex construction that involves the interaction of different social groups. The production of knowledge is not a construction outside of society, it develops within it, based on its interests, codes and systems. On the other hand, innovation is understood as the effective social incorporation of knowledge in the solution of problems or the establishment of new relations. It is nothing more than the interaction between groups, artifacts, and social cultures of experts and non-experts. Appropriation is not a passive reception; it always involves an interpretive exercise and the development of reflective practices. (Colciencias, 2020)

Thus, the proposed and executed strategy was focused on developing guidelines at all levels mentioned above, involving all the stakeholders in the scope and impact of the project and who participated directly in the exercise of knowledge co-creation, i.e., academia, informal recyclers, recyclers associations, college students, institutions at district level in the city of Bogotá, and all collaborators in the strategy development and in the transmission and collective construction of knowledge about problems of inadequate disposal and separation of waste at the source (domestic), with its corresponding impact on the environment and health of the recyclers.

\section{METHODOLOGY}

For the purpose of the research in the project "Social Innovation for Communication of Labour Risk Factors for Informal Recyclers in the Locality of San Cristóbal Sur Bogotá", the author conducted fieldwork with the committee of informal recyclable material collectors $^{3}$ (recyclers) in a locality of Bogotá as a case study, with a non-probabilistic by convenience sample, owing to limitations of access and availability of the population object of study. To establish the study variables in a qualitative approach, 70 participant observations were made, based on that prescribed by standards NTC 4114 and NTP 386 for workstation planned observations, complemented by a panel that allows the establishment of important aspects of labour risks from the main actors, which were informal workers. For this technique, social mapping was used, thereby allowing the establishment of recycling routes, most frequent accidents, symptoms associated with diseases resulting from work, and trends and prevalence together with the other instruments of data collection used.

The results were recorded in a matrix identifying risks and hazards based on that prescribed by standard GTC45 (see results on Table 1) and subsequently developed together with the actors, the strategy of social innovation and of social appropriation of knowledge. This was

\footnotetext{
${ }^{3}$ A self-established committee of informal workers which aims to represent them towards all Colombian government officials.
} 
represented in a short film describing the associated and identified risks and thoughts of the actors regarding its management, with the aim of transmitting these findings and reflections in the development of a strategy of knowledge communication, carried out with relevant actors in the chain of consumption and waste generation, who in turn with their practice of final disposal generate these risks associated with work-related accidents and diseases among the recyclable material collectors.

In this way, the author sought to establish a reflection in the communities involved in the project, identify possible solutions, and explore through a method of social innovation called the "time machine"4 (Puello-Socarrás \& Ballén, 2021), which was based in turn on a social innovation methodology developed by the I.School 5 of the Faculty of Engineering at the University of Tokyo. This reflection and co-created solutions were ultimately achieved with the inspiration and connection with the reality of the actors, their experiences and needs.

\section{RESULTS}

The major results of the instruments used are related as follows.

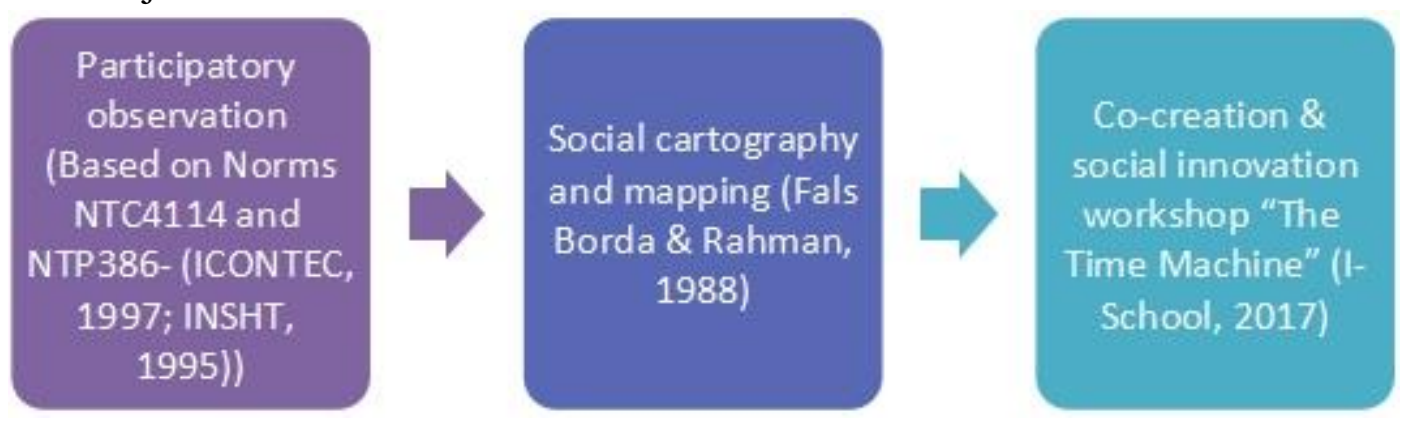

Figure 5. Research and Creation Strategies used in the co-creation of control measures in the management of occupational risk factors for the job of informal recyclers in the town of San Cristóbal Sur - Bogotá. Source: Own design

The results of participant observation based on NTC4114 / NTP386 and social cartography and mapping facilitated the following findings, analysed under criteria of the matrix of valuation of risks and hazards defined in standard GTC45 (ICONTEC, 2012):

\footnotetext{
${ }^{4}$ This "time machine" strategy is presented in length in the book authored by Puello-Socarrás \& Ballén (2021) Safety and Health for the informal worker - Social innovation Route for decent work. In this paper is presented briefly in figure 6. ${ }^{5}$ Innovation School, led by proffessor Shunsaku Komatsuzaki, who taught UNIMINUTO researchers and collaborators about the basics of Social Innovation Mindset and stimulated the creation of the author's "time machine" strategy for the understanding and knowledge apprehension of the different risk factors associated to the chain of consumption and waste generation, finally inspiring community-driven solutions for this issue.
} 
International Journal of Innovation, Creativity and Change. www.ijicc.net

Volume 15, Issue 10, 2021

Table 1. Results and findings of observation from the risk and hazard assessment matrix defined in standard GTC45. Source: Own design based on GTC45 (2012)

\begin{tabular}{|c|c|c|}
\hline \multicolumn{2}{|r|}{ RISKS AND DANGERS } & \multirow{2}{*}{$\begin{array}{l}\text { POSSIBLE NEGATIVE EFFECTS } \\
\text { ON SAFETY AND HEALTH }\end{array}$} \\
\hline Type of Risk & $\begin{array}{c}\text { Danger and potential hazard description (Obtained from } \\
\text { NTC4114 and/or NTP386 observations) }\end{array}$ & \\
\hline \multirow[t]{2}{*}{ BIOMECHANICAL } & $\begin{array}{l}\text { Transportation of materials. Ergonomic techniques for } \\
\text { lifting, hauling and pushing of heavy loads. }\end{array}$ & Cervical and low back pain \\
\hline & Posture (long held, forced, anti-gravitational) & $\begin{array}{l}\text { Physical and mental fatigue and } \\
\text { musculoskeletal disorders }\end{array}$ \\
\hline \multirow[t]{3}{*}{ PHYSICAL } & Noise & $\begin{array}{l}\text { Loss of hearing or deafness, } \\
\text { headache, and irritability }\end{array}$ \\
\hline & Ionizing radiation (radiation produced by solar exposure) & $\begin{array}{l}\text { Irritability, migraines, physical } \\
\text { exhaustion, stress, burns, } \\
\text { allergies, heatstroke }\end{array}$ \\
\hline & Lighting (excessive/insufficient light) & $\begin{array}{l}\text { Headache, eye pain and irritation, } \\
\text { stress, fatigue, work accidents, } \\
\text { visual pathologies }\end{array}$ \\
\hline CHEMICAL & $\begin{array}{l}\text { Solids (organic dust, inorganic dust, fibers, metallic and } \\
\text { non-metallic fumes), infectious substances }\end{array}$ & $\begin{array}{l}\text { Irritation and/or respiratory tract } \\
\text { illness }\end{array}$ \\
\hline \multirow[t]{2}{*}{ BIOLOGICAL } & $\begin{array}{l}\text { Bacteria - contact with contaminated recyclable materia } \\
\text { (Recently including COVID-19) }\end{array}$ & $\begin{array}{l}\text { Infections, irritation, rash and } \\
\text { inflammation of the skin, viral } \\
\text { diseases, general discomfort. }\end{array}$ \\
\hline & Exposure of waste management and pest control & $\begin{array}{l}\text { Waste storage, management and } \\
\text { control of pests, final disposal of } \\
\text { waste }\end{array}$ \\
\hline PSYCHOSOCIAL & Characteristics of the social work group & $\begin{array}{l}\text { Depression, stress, anxiety, sleep } \\
\text { problems, digestive system } \\
\text { disorders, headaches, } \\
\text { demotivation }\end{array}$ \\
\hline UNSAFE CONDITIONS & Risk of accidents & $\begin{array}{l}\text { Bumps/cuts by objects or tools, } \\
\text { projection of fragment or particles }\end{array}$ \\
\hline PUBLIC RISK & Robberies and holdups, attacks & $\begin{array}{l}\text { Multiple traumas, injuries, burns, } \\
\text { death }\end{array}$ \\
\hline
\end{tabular}

Meanwhile, social mapping allowed the author to establish from the voice of the actors that which had already been observed, that the most common in the recycling endeavour are gastrointestinal diseases and those of the skin via exposure to irritating chemical substances and biological agents, more recently, COVID-19 exposure became a major concern for this communities. Further, the most common in terms of accidents and incidents are punctures and cuts from the handling of materials such as cans and waste glass with sharp edges, which on numerous occasions cause injuries to their upper limbs.

\section{Co-creation workshop and social innovation strategy: "the time machine"}

According to the aforementioned findings, the co-creation workshop was developed with the concerned communities, which was considered essential to the development of communication strategies (audio-visual media) that facilitated the communication of risks factors and hazards derived from research findings to all interested parties. 
International Journal of Innovation, Creativity and Change. www.ijicc.net

Volume 15, Issue 10, 2021

In conclusion, the co-creation workshop called "the time machine" was developed, in which all actors shared their views, knowledge and experiences to contribute to proposed solutions to the situation of risk and hazards that informal workers present in their daily activities.

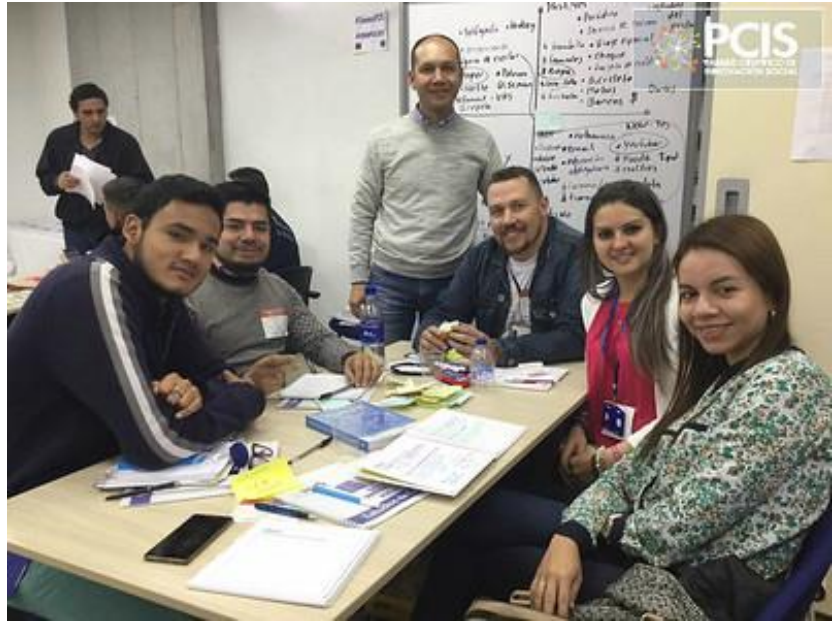

1- The creative team: D-Mentes Creativas (Creative D-Minds)

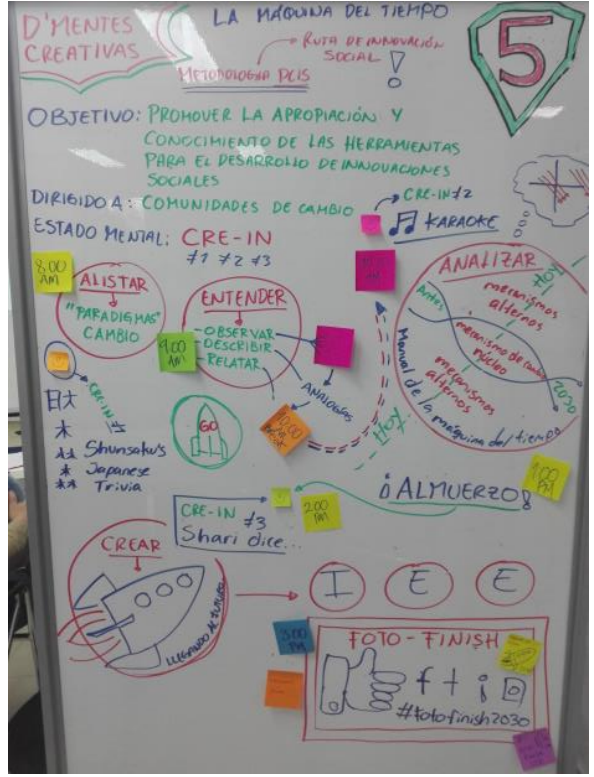

2- Mapping the mindset: "The time machine" - Social Innovation Strategy

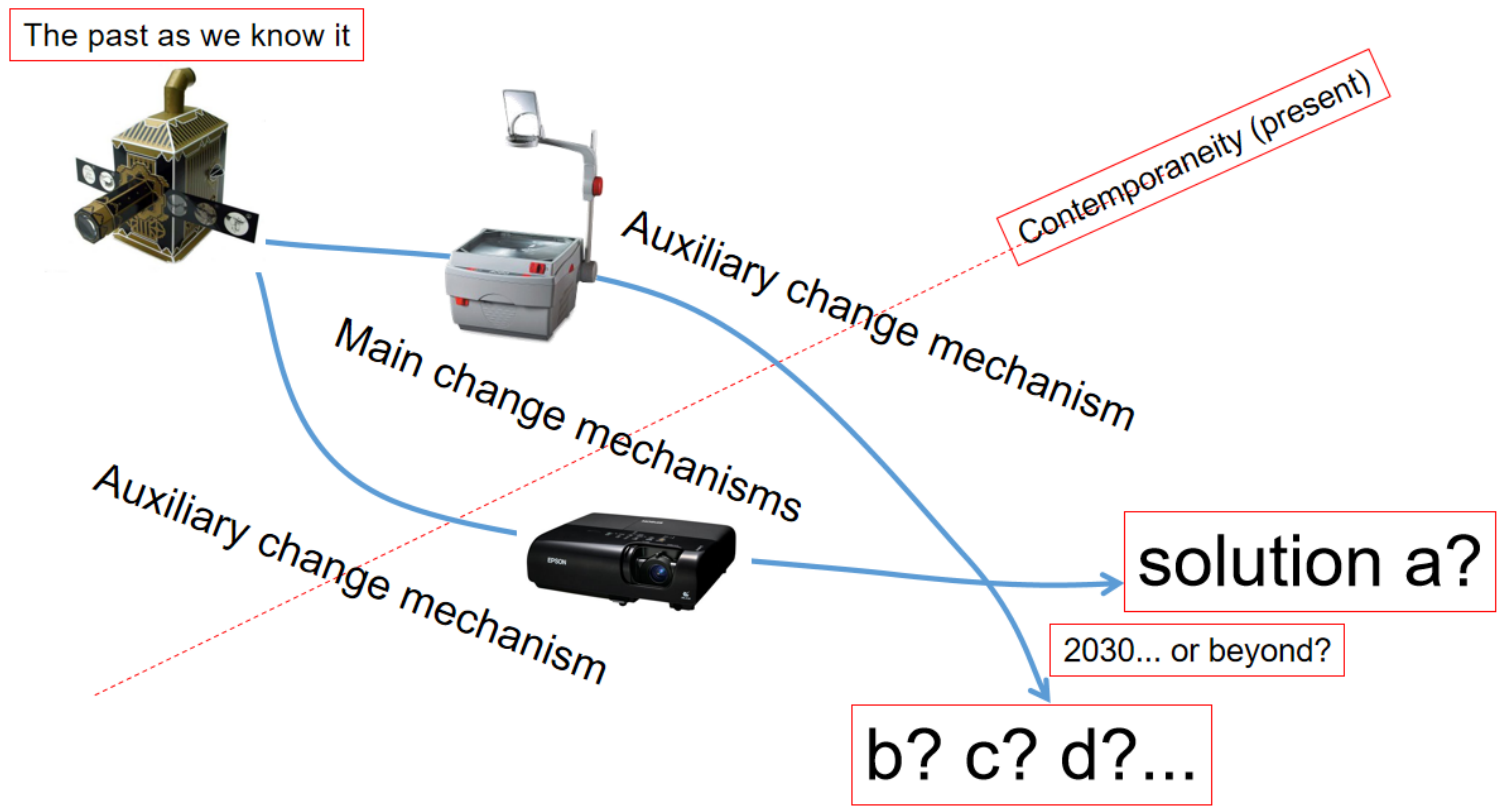

3- "The time machine" - Social Innovation Strategy main elements 
Figure 6. "The time machine" social innovation strategy mindset main stages. Source: Own design based on Shunsaku Komatsuzaki's Social Innovation Workshop IDEAPCIS 2017 for UNIMINUTO (2017)

"The time machine" main concepts are rather simple: Once all interested parties are summoned, a "trigger" is delivered by the workshop moderators, this time the trigger is an audio-visual media presenting all risks and hazards informal workers are exposed to. After the audio-visual is presented to the audience, then the basics of the time machine are explained to all parties, asking them to group up. Groups should mix participants heterogeneously, ensuring that all groups include participants from different communities.

Once groups are formed, all participants should think and discuss the situation presented in the triggering video (risks and hazards for informal workers) among their groups around the following questions:

- How were things in the past? $(5,10,20$ years ago?)

- How are things now?

- What changed between the past and the present?

- What were the main change mechanisms (most important) that forged that change?

- What were the auxiliary change mechanisms (less important) that forged that change?

Participants are asked to draw and write down in a large sheet of paper, previously provided, all of the main aspects of the discussion, their ideas, conclusions and relevant findings derived from their group dissertations during the exercise, overseeing and upholding their discussion from time to time by moderators.

Once done, moderators ask the participants to try and think of the present as if it were the past already. This time, using main change mechanisms and/or auxiliary change mechanisms altogether as mind setting conditions for change.

Then the moderators ask participants to discuss, draw and think of solutions or changes to the issue within a future time frame (10 - 20 - 30 years into the future) considering the previously set change mechanisms.

Finally, results are presented by the different groups to the audience and their results and thoughts are shared through their social media, to enhance discussion and reach beyond, as presented in figure 7 and 8 : 
International Journal of Innovation, Creativity and Change. www.ijicc.net Volume 15, Issue 10, 2021

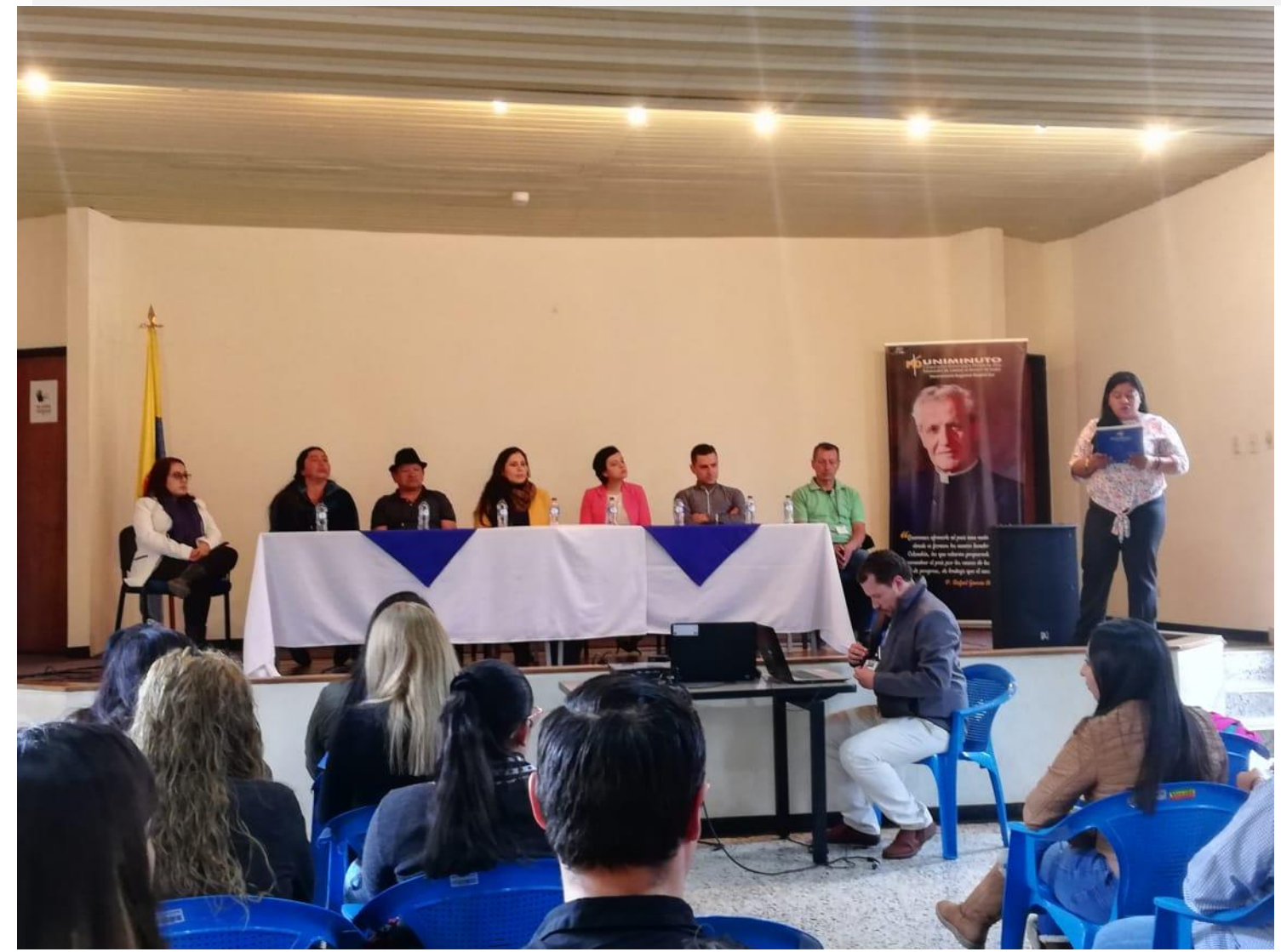

Figure 7. Setting of "The time machine" workshop for co-creation of solutions to the issue of risks and hazards for informal workers.

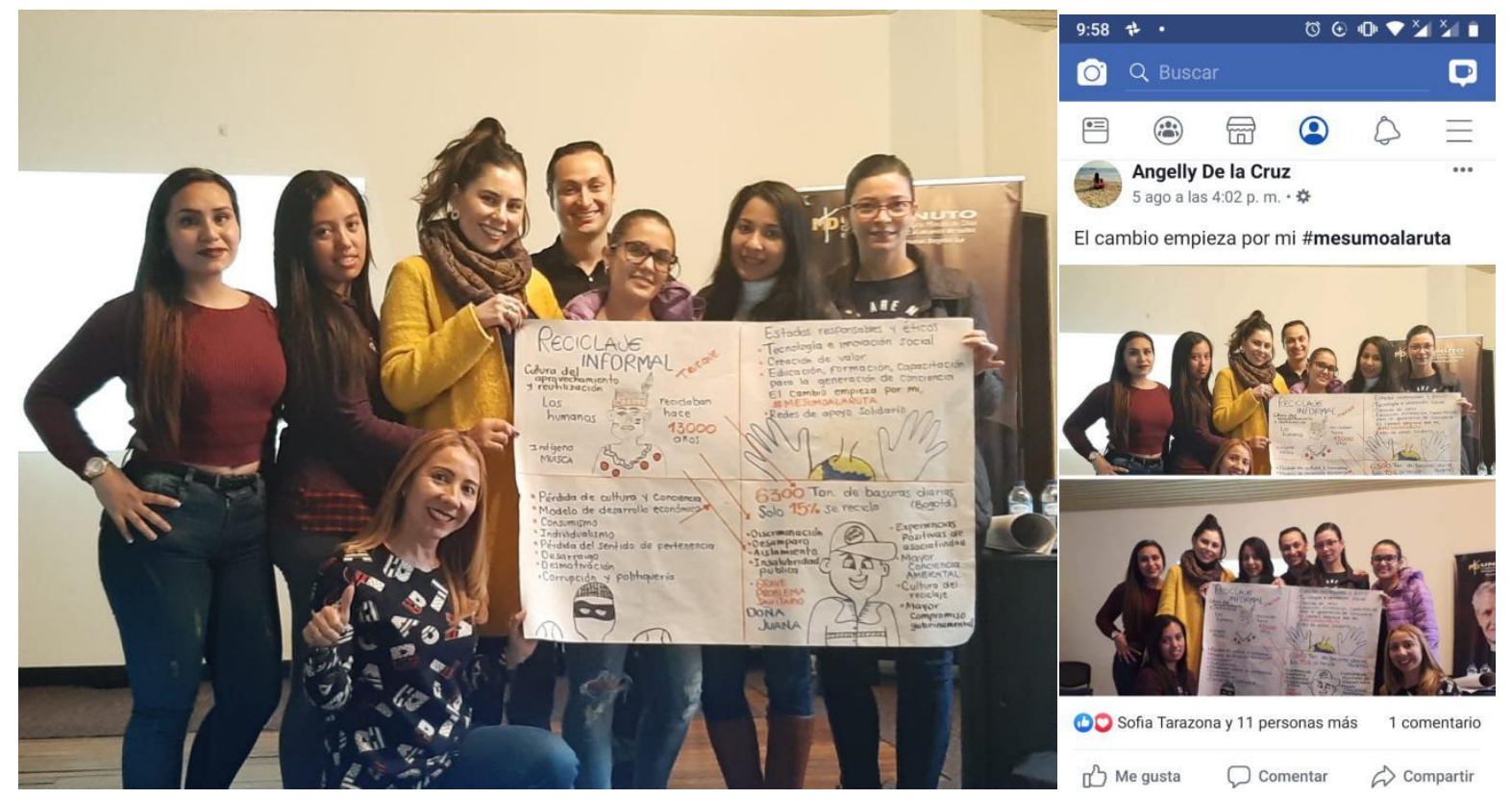

Figure 8. Presenting results of the workshop to the audience and through social media CONCLUSIONS 
As the conclusions presented by Nicolas, from the university of Philippines Dilliman in his paper "Promoting Mental Health through Creativity in Social Work Practice: The Role of Preparation and SelfCare" when he says:

The onset of the 2020 Coronavirus pandemic proves that social workers continue to thrive in a world characterised by risk, uncertainty, and chaos. As such, creativity is key in adapting to such an environment and in promoting mental health among service users and social work practitioners. (Nicolas, 2021)

Following this same line of thought, the author of this article firmly believes that the best source of change is creativity and adaptability. In this way, by creating joint solutions by the different actors of the consumption and waste disposal chains, it is possible to face common challenges in terms of risks and dangers that informal workers are exposed to in their daily activities. In the same way and in terms of human development, the participants of these consumption chains become key actors for social change and environmental sustainability. Consequently, with these creative processes, improvement in working conditions can be promoted, with more dignity for the workers who face precarious labour conditions today.

In the end, the participants reflected on their role in the chain of consumption and waste disposal, integrating best practices for the better waste disposal, this way mitigating the risks and dangers to the work activity of informal recyclers. For their part, recyclers became more aware of their self-care and improved the means of protection they use to avoid such risks in their activities.

Thus, discussion focuses on how professionals in worker safety and health faced by the challenges and dynamics posed by informal work in Colombia, (which corresponds to around $46.7 \%$ of the active Colombian labour population $\left(\mathrm{DANE}^{6}, 2020\right)$ ), can turn to novel and disruptive strategies with the goal of contributing to solutions of the problems afflicting these informal working populations, issues of safety and health at work in the informal field, and situations affecting public health and equity in accessing decent work, with the help of innovation and social change techniques such as "The time machine" strategy, presented in this paper.

\section{CONFLICT OF INTEREST}

The author declares that there are no conflict of interest regarding the publication of this paper.

\footnotetext{
${ }^{6}$ DANE by its spanish name, a Colombian government entity which represents the main source of data and statistics on diverse matters of the country.
} 


\section{RESEARCH FUNDING:}

This paper was funded by the UNIMINUTO research project No. C120-271 "Social Innovation Strategy focused on the appropriation of knowledge about risk factors for health and occupational safety in informal workers of mining industries in PDET territories, the south of Bogotá and Villavicencio (2020)" and the author acted as its main researcher.

\section{LIMITATIONS OF THE STUDY}

All subjects involved in the study and whose results are presented in the research gave informed consent for use of the data presented herein; however, some of the results were obtained with the participation of young scholars. These results are not available or presented in this paper.

The present study was also limited by access difficulties to the informal workforce community, due to people work shifts and recycling routes. The data was taken based on observation instruments focused on the formal working population and on workplace inspections developed within formal businesses, because at present there are no instruments of data collection standardized for studies of an informal labour population.

\section{ACKNOWLEDGEMENTS}

Special thanks to the International Journal of Innovation, Creativity and Change for allowing the publication of this article, to UNIMINUTO Research Staff, Professor Claudia Milena Ospina Lopez, Professor Shunsaku Komatsuzaki, from I.School (University of Tokio Japan), the D'Mentes Creativas Group which participated in the creation of "The Time Machine"; to informal recyclers who participated in the workshop, to Dr. Dionne Alexandra Cruz Arenas ${ }^{7}$, for her invaluable contributions, to Martha Patricia Ávila, Ana Emelis Obregón and Axel Rodríguez Peña, without whose support this project would have been impossible.

\footnotetext{
${ }^{7}$ President of the Colombian Public Health Association
} 
International Journal of Innovation, Creativity and Change. www.ijicc.net

Volume 15, Issue 10, 2021

\section{REFERENCES}

Arias, J. (2016) Estudios de Caso 5.1 Innovación Social, concepto ligado a la práxis; caso Parque Cientifico de Innovación Social de UNIMINUTO - Colombia

Bateson, G.; Ruesch, J. (1984) Comunicación. La matriz social de la Psiquiatría, Paidós, Barcelona.

Berlo, D. K. (1969). El proceso de la comunicación: introducción a la teoría ya la práctica (No. 159.9). El Ateneo.

Center for Disease Control and Prevention - CDC (2016) Workplace Health Model. CDC.gov website.

Retrieved

from:

https://www.cdc.gov/workplacehealthpromotion/model/index.html

Chaves Bazzani, L. (2020) Promoción de la salud en los lugares de trabajo: Un estado del arte [Maestría]. Universidad Nacional de Colombia.

Colciencias (2020) Estrategia Nacional para la apropiación social del conocimiento. Colciencias.gov.co website retrieved from: https://www.colciencias.gov.co/sites/default/files/ckeditor_files/estrategia-nacionalapropiacionsocial.pdf

Departamento Administrativo Nacional de Estadistica. (2020). Medición de empleo informal y seguridad social. Octubre de 2.019 (COM-030-PD-001-r004). Retrieved from https://www.dane.gov.co/files/investigaciones/boletines/ech/ech_informalidad/bol_ech informalidad_ago19_oct19.pdf

Fals Borda, O. \& Rahman, M.A. (1988) Romper el monopolio del conocimiento: Situación actual y perspectivas de la Investigación-Acción Participativa, Análisis político No. 5 Sept- Dic. 1988. Pags. 46-55. Bogotá. Retrieved from: https://revistas.unal.edu.co/index.php/anpol/article/download/74123/66990/393140

Fisas, V. (1987). Introducció a l'estudi de la pau i dels conflictes. Fundació Jaume Bofill.

Frascara, J. (2000) Diseño Gráfico y Comunicación. Buenos Aires. Ed. Infinito

ILO (2014) La transición de la economía informal a la economía formal. ILO.org website. Retrieved from: http://www.ilo.org/wcmsp5/groups/public/@ed_norm/@relconf/documents/meetingdoc ument/wcms_218350.pdf

ILO (2018) Objetivo \#8: Trabajo decente y crecimiento económico (La Agenda de desarrollo 2030) ILO.org website. Retrieved from: http://www.ilo.org/global/topics/sdg2030/goal-8/lang--es/index.htm

Instituto Colombiano de Normas Técnicas. (1997). Norma Técnica Colombiana NTC4114:1997. Bogotá: ICONTEC. Retrieved from: http://199.89.55.129/scorecolombia/documents_co/herramientas/M5/Material_tecnico apoyo/SGSST_2015/3.\%20Planificaci\%C3\%B3n/6.\%20Controles/COPASST/Cartillas/ NTC_4114_Realizacion_de_Inspecciones_Planeadas_ICONTEC.pdf

Instituto Colombiano de Normas Técnicas. (2012). GUÍA PARA LA IDENTIFICACIÓN DE LOS PELIGROS Y LA VALORACIÓN DE LOS RIESGOS EN SEGURIDAD Y 
International Journal of Innovation, Creativity and Change. www.ijicc.net Volume 15, Issue 10, 2021

SALUD OCUPACIONAL. Bogota: ICONTEC. Retrieved from: http://132.255.23.82/sipnvo/normatividad/GTC_45_DE_2012.pdf

Instituto Nacional de Seguridad e Higiene en el Trabajo. (1988). NTP 386: Observaciones planeadas del trabajo. Madrid, España: Ministerio de Trabajo y Asuntos Sociales de España. Retrieved from: https://www.cso.go.cr/legislacion/notas_tecnicas_preventivas_insht/NTP\%20386\%20\%200bservaciones\%20planeadas\%20del\%20trabajo.pdf

LaboUR, Observatorio de Informalidad Laboral de la Universidad del Rosario (2018). Perfil actual de la informalidad laboral en Colombia: Estructura y Retos. Universidad del Rosario, Observatorio Laboral Laboral de la Universidad del Rosario, Informe, (6).

Lederach, J. P. (1992). Enredos, pleitos y problemas: una guía práctica para ayudar a resolver conflictos. Clara.

Lorenzo Cadarso, P. L. (1995). Principales teorías sobre el conflicto social.

Nicolas, J.F. (2021) International Journal of Innovation, Creativity and Change. www.ijicc.net Volume 15, Issue 1, 2021 - Special Edition. Retrieved from: https://www.ijicc.net/images/Vol_15/Iss_1/15103_Nicolas_2021_R.pdf

Organización Internacional del Trabajo - OIT (2018) La economía informal emplea más de 60 por ciento de la población activa en el mundo, según la OIT. OIT-ILO website. Retrieved from https://www.ilo.org/global/about-theilo/newsroom/news/WCMS_627202/lang--es/index.htm

Organización Internacional del Trabajo - OIT (2020) Trabajo Decente. OIT-ILO website. Retrieved from http://www.oit.org/global/topics/decent-work/lang--es/index.htm

Organización Panamericana de la Salud Organización Mundial de la Salud División de Salud y Ambiente. (2000) Estrategia para el fortalecimiento de la promoción de la salud en los lugares de trabajo en América Latina y el Caribe. 1st ed. San José, Costa Rica.

Pardo, D. (2021) "El Paro Nacional nos afectó más que la pandemia": el estallido social visto por los empresarios (y por qué creen que es una oportunidad para Colombia). Website of BBC News. Retrieved from https://www.bbc.com/mundo/noticias-america-latina57366819

Puello-Socarrás, G., \& Vargas Puentes, L. (2019). Salud Ocupacional y su enfoque social dentro de trabajos de grado en universidades de Bogotá. EducacióN MéDica Superior, 33(1). Retrieved from http://ems.sld.cu/index.php/ems/article/view/1595

Puello-Socarrás, G.E. \& Ballén V., D.M. (2021) Seguridad y Salud para el trabajador informal -Ruta de innovación social para el trabajo digno. Centro Editorial UNIMINUTO. Bogotá, Colombia.

Puello-Socarrás, G.E.; Obregón Flórez, A.E.; Serna Rubio, A.C. \& Ballén Buitrago, D.M. (2021) Report of risk factors in informal waste recovery workers in the town of San Cristóbal - Bogotá. 37 ${ }^{\text {th }}$ IBIMA Conference Proceedings. 30-31 May, 2021. Cordoba, Spain. ISBN: 978-0-9998551-6-4.

Puello-Socarrás, GE (2019) Emprendimiento e innovación, claves del desarrollo: Reflexiones desde la perspectiva de seguridad y salud en el trabajo (pág. 135-159) en Peña-Lapeira, 
CJ. El emprendimiento social y la innovación como motor del crecimiento empresarial. Centro Editorial UNIMINUTO, Bogotá.

Sachs, J. D. (2009). Rethinking macroeconomics. Capitalism and Society, 4(3), 14-15. Retrieved from http://www.bibalex.org/Search4Dev/files/333952/167175.pdf

UNIMINUTO (2020) Líneas de investigación - Portal UNIMINUTO. uniminuto.edu website. Retrieved from: http://www.uniminuto.edu/-/lineas-de-investigaci8?inheritRedirect=true

UNIMINUTO (2021). Innovación centrada en el ser humano IDEA PCIS 2017. Uniminuto.edu website. Retrieved from: http://umd.uniminuto.edu/web/pcis/noticias//asset_publisher/fDB7fepAXsNX/content/innovacion-centrada-en-el-ser-humano-ideapcis-

2017/pop_up?_101_INSTANCE_fDB7fepAXsNX_viewMode=print\&_101_INSTAN CE_fDB7fepAXsNX_languageId=pt_BR 